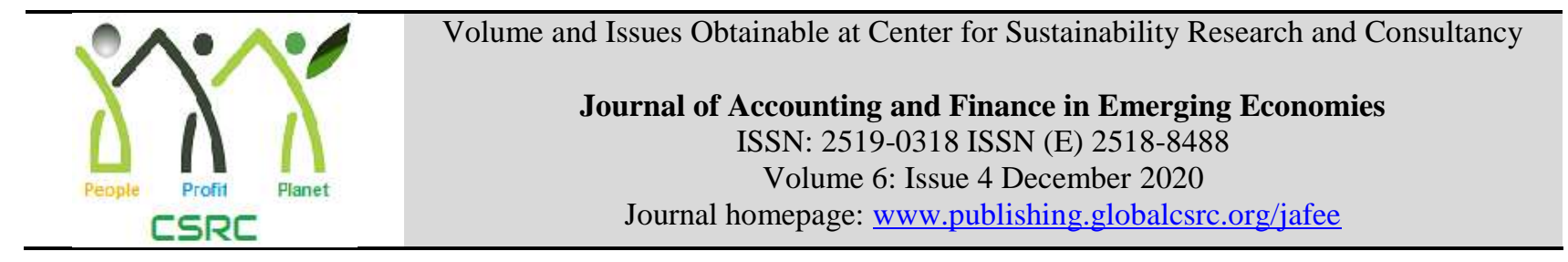

\title{
The Moderating Effect of Special Peer Support on the Relationship between Remuneration and Employee Commitment
}

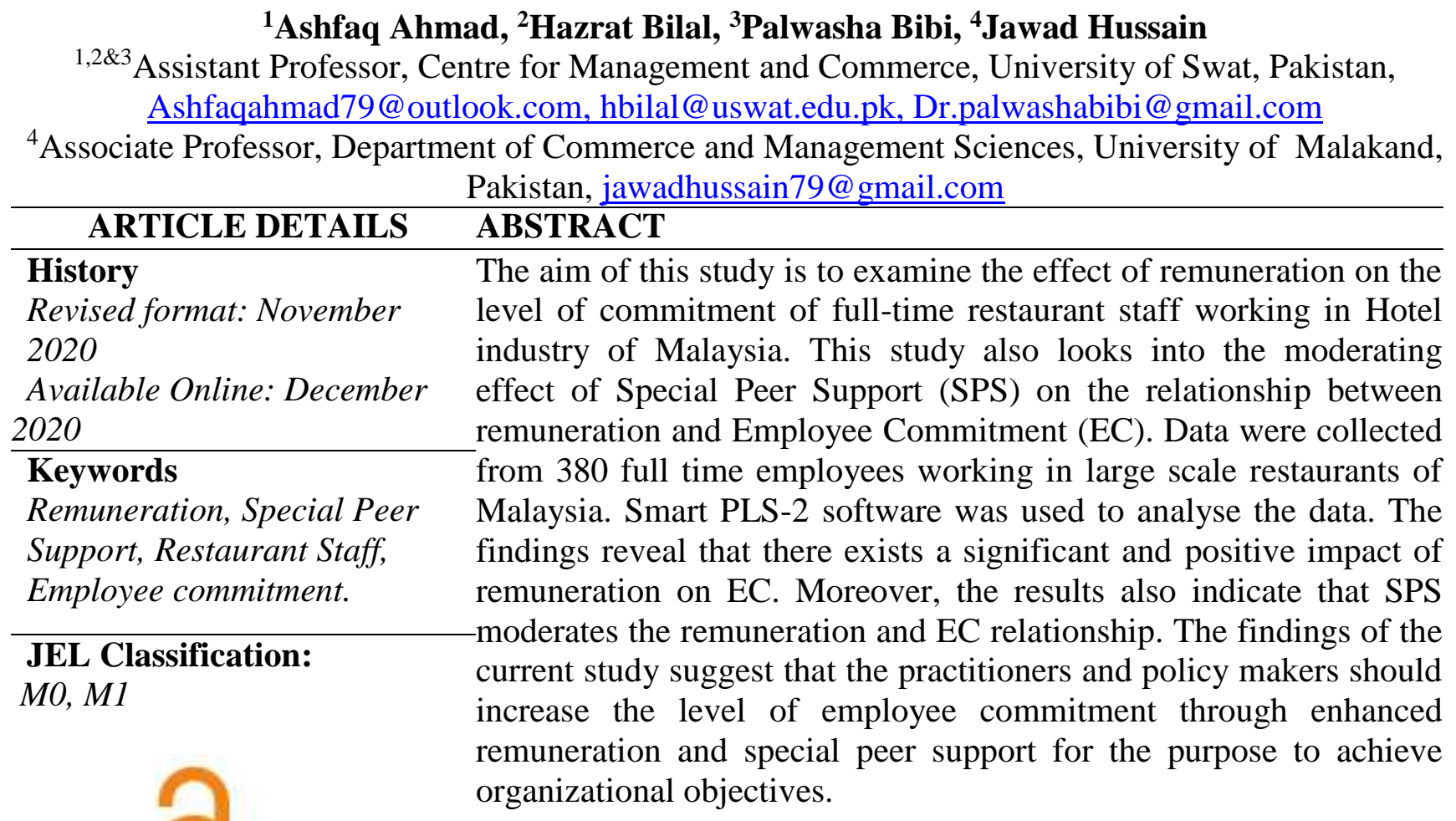

(C) 2020 The authors, under a Creative Commons Attribution-

NonCommercial 4.0

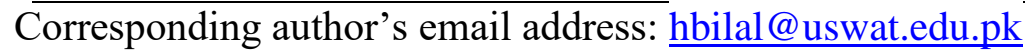

Recommended citation: Ahmad, A., Bilal, H., Bibi, P. \& Hussain, J. (2020). The Moderating Effect of Special Peer Support on the Relationship between Remuneration and Employee Commitment. Journal of Accounting and Finance in Emerging Economies, 6(4), 1033-1040

\section{Introduction}

Hospitality industry positively affects the local businesses, as visitors spend more money in hotels, resorts and convention centres. It also benefits the economy since visitors purchase various goods and avail services. Moreover, they purchase locally manufactured products, souvenirs and accessories. The role of service industry in the economic and social development of both the developing and developed countries has been recognized. The role of workers in the service sector is inevitable and they need to be motivated. Highly motivated employees are valuable assets of any organization. Previous research has emphasised that highly devoted and committed employees are vital and each of them can contribute to the success of the organization (Ismail, Zainuddin, \& Ibrahim, 2010).

However, the lack of committed and motived employees is still a major issue for the hotel industry, especially in Malaysia (Federation of employers in Malaysian, 2011). These days, companies face more challenges in their pursuit of greater business. Hence, the commitment of employees to their professions and their organisations is vital, because it is one of the determinants of organisational performance. For 
example, committed employees are likely to spend extra time and effort to achieve organizational goals (Ali, Rehman, Ali, Yousaf, \& Zia, 2010). Thus, retaining of highly motivated and committed workers is therefore an essential and recent concern in the tourism sector in Malaysia. Likewise, previous researchers such as Davidson et al., (2010) and Ishak et al. (2011) have argued that perhaps the tourism sector has been experiencing a high employee turnover, and this situation has adversely affected the long-term growth and survival of the companies in shape of poor job performance, profitability, client services and safety standards. Therefore, management should take steps to mitigate the employee turnover rate in their organisations, for which they need to investigate the significant factors that contribute to the employees' turnover. The major factors contributing to turnover in the service sector in Malaysia include the salary, wages and remuneration of employees as well as support from supervisors (Sangaran \& Jeetesh, 2015).

\subsection{Rationale of the Study}

Previous research has been conducted on remuneration, SPS and EC, but little attention has been given to these factors in the context of hospitality industry of Malaysia. Moreover, the majority of the prior studies investigating the interplay between the peer support, remuneration and employee commitment have been conducted in the developed countries while, less attention has been paid to the interaction between the mentioned constructs in the developing economies. Thus, the purpose of the study is to investigate the moderating role of SPS on the relationship between remuneration and employee commitment in a developing economy's context like Malaysia.

\section{Literature review}

\subsection{Employee Commitment}

Commitment can be defined as feeling of obligation by exerting effort towards organizational goals (Porter, Steers, Mowday, \& Boulian, 1974). Employee commitment is associated with many factors of job behavior like job satisfaction, turnover, employee performance and organizational citizenship behaviors (Porter et al., 1974; Tran, Nguyen, Nguyen, \& Ton, 2020). Commitment is viewed as a more active and positive attitude towards the organization (Aswathappa \& Dash, 2020; Chhabra, Ubeja, \& Sharma, 2020). J. P. Meyer and Allen (1997) explained that "commitment is arguably one of the most important factors involved in employees support for change initiatives". EC shows a worker's emotional attachment to that organization where he/she works, and will stay there due to that degree of attachment with the organization (p.474).

Employees who have a higher degree of commitment towards their organization are less likely to leave than those who are less committed (Albrecht \& Marty, 2020; Liu, Wang, \& Liang, 2020; I. Meyer \& Nujjoo, 2012).This indicates that when organizations provide adequate remuneration and care for workers, it would make employees to stay longer with their organization (McEntee, Roche, Kostadinov, Hodge, \& Chapman, 2020). This phenomenon is consistent with the Social Exchange Theory (SET) of (Blau, 1964), which means that when workers get enough remuneration from the organization, they are more happy and thankful to pay back through dedication and sense of commitment (Adams \& Jacobsen, 1964). In addition, enormous work is being carried out on EC in different sectors and counties, while there is still little data available from underdeveloped countries, especially in the Malaysian context. Prior researchers like Balay (2000) argued that there is still limited research available on EC, therefore, This research is an attempt to explore the linkage of remuneration and EC between the hotel industries of Malaysia.

\subsection{Remuneration and Employee Commitment}

Previous research noted that in the tourism industry, Human Resource Management (HRM) practices such as pay, job satisfaction, career growth and many other factors leading to EC and enhanced organizational performance. It has been contended that turnover ought to be decreased in firms where HRM practices are seen and managed as investment in the professional development of employees (Allen, Shore, \& Griffeth, 2003). Likewise adapting proper HRM practices enhances commitment, 
decreases turnover and increases the rate of retention (Chanda \& Goyal, 2020; Memon et al., 2020). Similarly, compensation is the primary influencing tool for employees. Many organizations have been using this tool to inspire, motivate and retain skilled and experienced workers (Mendis, 2017).

By providing adequate compensation to individuals working in the organization has a reassuring effect on both employees' and organizational performance. Remuneration is a competitive advantage for the company to improve performance and employee commitment (Ahmad, Shah, Bibi, \& Shah, 2017). Similarly, Milgo, Namusonge, Kanali, and Makokha (2014) asserted that the compensation has an impact on the organizational commitment. Ahmad et al. (2017) reported that remuneration is the main tool to motivate employees and enhance their EC. Thus, employee commitment helps an organization to achieve the desired organizational goals (Berberoglu, 2018; Singh, 2019).

Most of the factors that impact EC have been explored and tested empirically by different scholars, although, contradictions emerge from the empirical results of each review, such as studies conducted by Ahmad, et al. (2019) and Ahmad, Shah, Bibi, \& Shah (2017) reported that there is a positive and significant link between remuneration and commitment. While, Chew and Chan (2008) and Nijhof, de Jong, and Beukhof (1998) claimed that remuneration is not always an adequate incentive to retain professional workers. The contradictory relationship between remuneration and the commitment of employees needs to be further explored. Henceforth, this research presumed that:

H1: If remuneration increases then employee commitment will also increase.

\subsection{Special Peer Support as Moderator}

Special peer support or Co-workers are the individuals who carry out their routine work at the same level in the organization (Ahmad, Abdul Majid, \& Mohd Zin, 2016). Recent research has shown encouraging evidence of association between social support, work stress and health of workers (De Rijk, Blanc, Schaufeli, \& De Jonge, 1998). Special peer support is therefore critical and plays a vital role in EC and employment-related patterns (Chiaburu \& Harrison, 2008).Similarly, Weasmer and Woods (2002) also revealed positive outcomes for SPS such as a positive feeling towards teaching, increased motivation, decreased job stress, enhanced career development, and improved work performance. SPS has the capability to produce a favorable or unfavorable climate. The previous studies have highlighted that supportive colleague makes job easier and joyful enough to enhance employee commitment and motivation (Ellickson \& Logsdon, 2001)

Similarly, Saif, Malik, and Awan (2011) contended that SPS is the primary predictor of employee commitment. Social Exchange Theory (SET) of Blau (1964) also suggested that when employee receive support from their organization as well as from peers, they feel to repay the organization in the form of devotion and commitment (Ahmad et al., 2016; Chaudhuri, 2011). A relatively very few studies have focused on examining SPS as a moderator in the workplace and its impact on EC. This study therefore suggests SPS as a moderator on the relationship between remuneration and the EC. On the basis of aforementioned arguments, we hypothesized that;

H2: Special peer support moderates the relationship between the remuneration and EC.

\section{Methodology}

\subsection{Procedure and Participants}

Survey data were collected from employees working in large scale restaurants located in different Hotels of Malaysia such as Terengganu, Sibu, cameron highlands, Putrajaya, Kuantan, Kalag, and Negeri Sembilan. Total 520 survey questionnaires were distributed randomly among the full-time employees, out of which 410 were returned back. Thirty partially filled questionnaires were discarded after which 380 questionnaires were found complete in all respects and thus used for the further analysis.

\subsection{Measurement}

This study used the previous measurement scales for assessing the constructs. Remuneration was 
measured by 5 items scale adapted from Teclemichael Tessema and Soeters (2006). EC was measured by 9 items scale adapted from Mowday, Steers, and Porter (1979). For measuring the SPS, the study adapted a 10 items scale from Ducharme and Martin (2000). All the items were measured on 5-point Likert Scale that allowed the responded to express the level of their agreement and disagreement between score ranges from 1 to 5 .

\section{Results}

\subsection{Convergent validity}

The data was analyzed using Smart-PLS version 2.0. To establish convergent validity in accordance with Hair, Anderson, Babin, and Black (2010), who suggested the three types of estimation including the factor loading, Average Variance Extraction (AVE) and the Composite Reliability (CR). As indicated in the Table 1, the items were found to be with loadings greater than 0.5 , thus were retained as mentioned by Hair et al. (2010). In total, 7 items (SPS 5, SPS 6, SPS 7, SPS 8, SPS 9, SPS 10, and RM1) were removed due to the loading less than the suggested threshold. The rest of the items, 17 in total, were retained. Table 1 also shows that $\mathrm{CR}$ for all the constructs was found to be greater than 0.7 , with the AVE values above 0.5, as suggested by Hair et al. (2010).

Table 1: Convergent Validity Analysis (Items, loading, AVE and CR)

\begin{tabular}{|c|c|c|c|c|}
\hline CONSTRUCT & ITEM & LOADING & AVE & $\mathbf{C R}$ \\
\hline \multirow[t]{4}{*}{ Rem* } & RM2 & 0.738 & 0.784 & 0.917 \\
\hline & RM3 & 0.801 & & \\
\hline & RM4 & 0.931 & & \\
\hline & RM5 & 0.890 & & \\
\hline \multirow[t]{4}{*}{ SPS** } & SPS1 & 0.894 & 0.782 & 0.923 \\
\hline & SPS2 & 0.819 & & \\
\hline & SPS3 & 0.823 & & \\
\hline & SPS4 & 0.783 & & \\
\hline \multirow[t]{9}{*}{$\mathrm{EC} * * *$} & EC3 & 0.764 & 0.731 & 0.941 \\
\hline & $\mathrm{EC} 4$ & 0.880 & & \\
\hline & EC5 & 0.837 & & \\
\hline & EC6 & 0.788 & & \\
\hline & EC7 & 0.887 & & \\
\hline & EC8 & 0.956 & & \\
\hline & EC9 & 0.946 & & \\
\hline & EC1 & 0.941 & & \\
\hline & EC2 & 0.611 & & \\
\hline
\end{tabular}

*Remuneration, **Special Peer Support, *** Employee Commitment

\subsection{Discriminant Validity}

For the current study, the discriminant validity was obtained by analyzing the square root of the AVE while comparing the outer loads with cross loadings (Duarte \& Raposo, 2010; Hair et al, 2013).

Table 2: The Square Root of AVE and the correlations of the latent variables

\begin{tabular}{cccc}
\hline & EC & REM & SPS \\
\hline EC & $\mathbf{0 . 8 4 1}$ & & \\
REM & 0.134 & $\mathbf{0 . 8 4 8}$ & \\
SPS & 0.191 & 0.330 & $\mathbf{0 . 8 6 7}$ \\
\hline
\end{tabular}

As reported in Table 2, the diagonal values are greater than the other value of the row and column in which they are located, thus highlighting and confirming the discriminant validity (Hair et al, 2010). 


\subsection{Structural model}

To examine the link between the remuneration, SPS and EC, the bootstrapping technique was used for data investigation. In addition, 5000 bootstraps were used to assess the structural equation model. The results of the conceptual framework are illustrated in Figure 1 and Table 3.

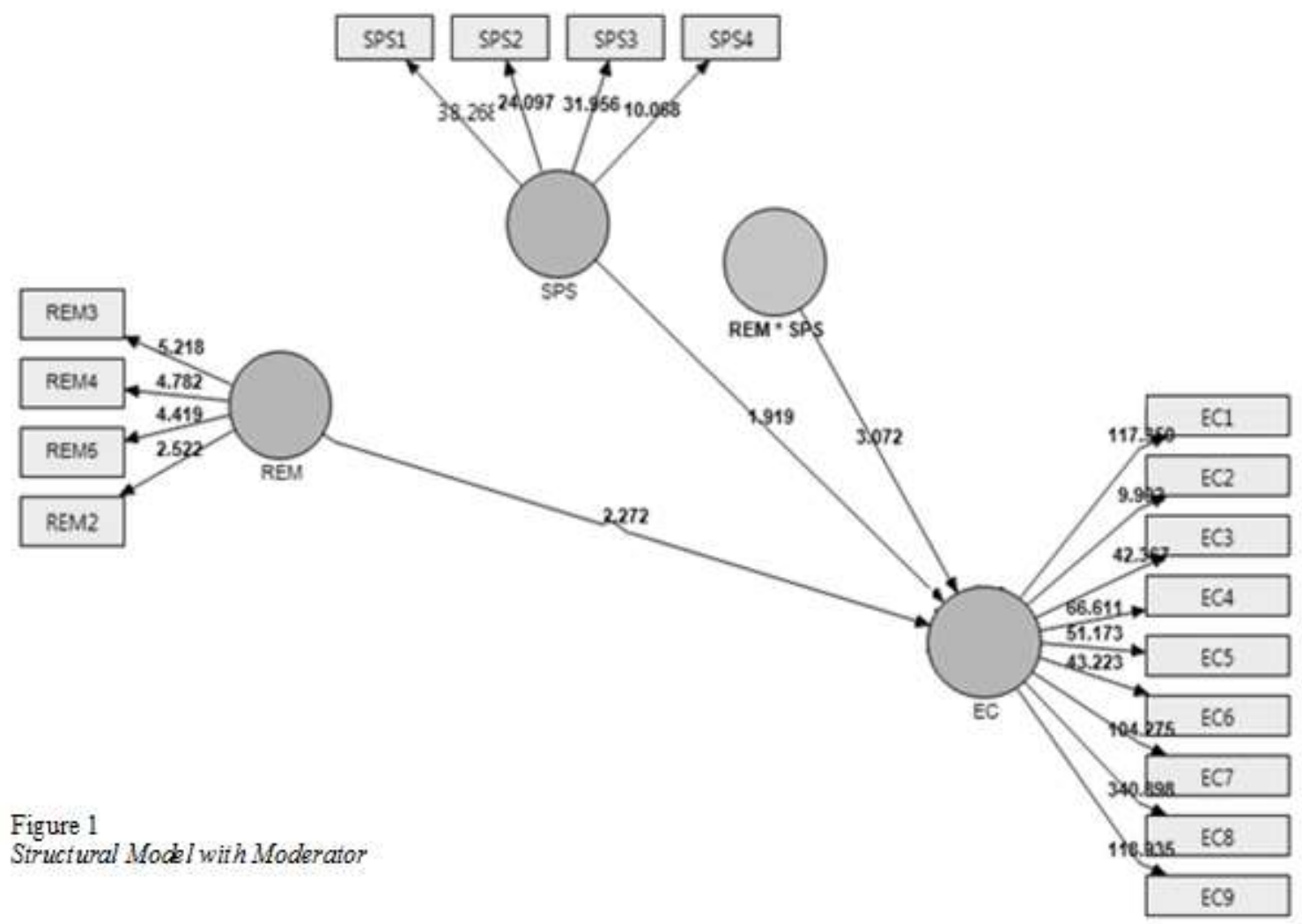

Table 3: The Results of Structural Model

\begin{tabular}{lccccr}
\hline Hypothesis & Relationship & $\begin{array}{c}\text { Beta } \\
(\boldsymbol{\beta})\end{array}$ & $\begin{array}{c}\text { Standard } \\
\text { Error } \\
(\text { STERR) }\end{array}$ & $\begin{array}{c}\text { T- } \\
\text { Statistics }\end{array}$ & $\begin{array}{c}\text { p- } \\
\text { value }\end{array}$ \\
\hline H1 & Remuneration > Employee Commitment & 0.187 & 0.085 & 2.371 & 0.01 \\
H2 & Remuneration * Special Peer Support - & 0.251 & 0.081 & 3.072 & 0.00 \\
& >Employee Commitment & & & & \\
\hline
\end{tabular}

Table 3 illustrates that there is a significantly positive correlation between remuneration and EC (beta=.187, t-value=2.37 and p-value<0.01). Hence, hypothesis 1 of the study is supported. Moreover, by using product indicator approach, the moderating effect of SPS was checked on the remuneration and EC link, as shown in Figure 2. The results (beta $=.251$, $\mathrm{t}$-value $=3.07$ and $\mathrm{p}$-value $<0.00$ ) indicated that SPS moderates the relationship between remuneration and EC. Hence, the hypothesis 2 of the study is supported. 


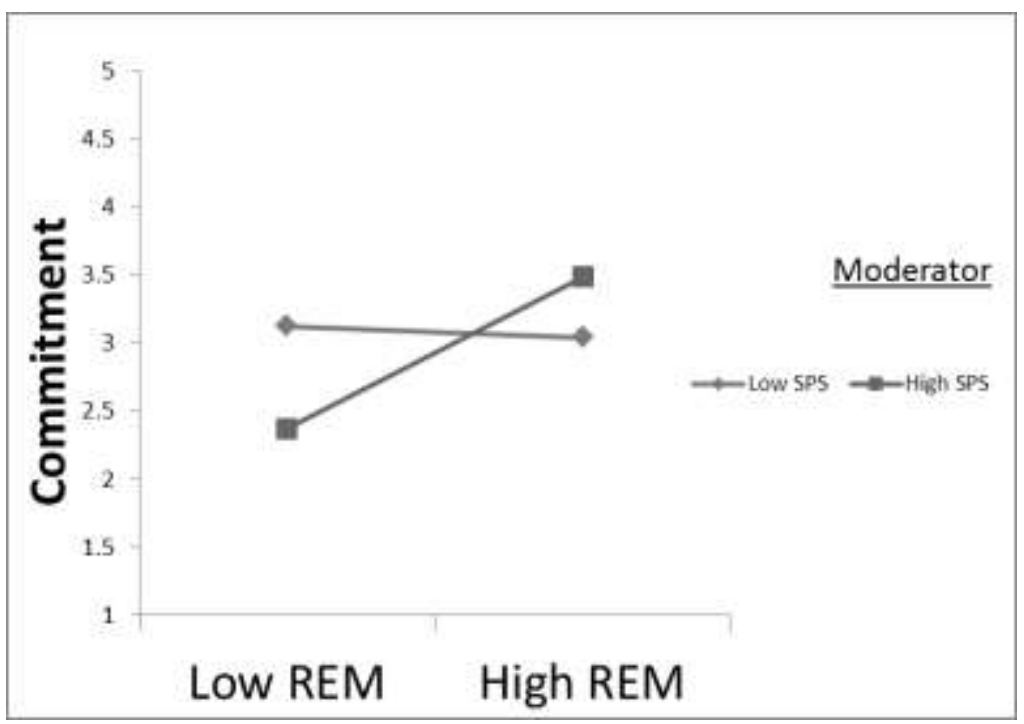

Figure 2 Interaction effect of remuneration and EC

\section{Discussion}

The aim of this study was to assess the effect of remuneration on EC in the context of large-scale restaurants in Malaysia. The results of the research indicated an imperative relationship between REM and EC. The findings of the current study are in line with the prior studies of Ashafaq Ahmad, Kura, Bibi, Khalid, and Rahman Jaaffar (2019) who have highlighted positive and significant effect of remuneration on EC. This suggests that if an organization creates a fertile work environment to its employees and provides them compatible remuneration, they will show positive behavior towards organization and will work with zeal and zest in exchange. Moreover, they become committed and will work with the organization for a longer period of time.

Moreover, the results indicated that SPS significantly moderates the relationship between remuneration and EC. In addition, employees feel more obliged and honored if they are supported by co-workers that further leads to enhancing the commitment level of employees. This situation also endorses the principle of reciprocity of the Social Exchange Theory of Blau (1964), which describes that workers who believe that the organization offers adequate remuneration, and receives adequate support from peer are proved to be more loyal and committed.

\section{Implications}

This study not only makes a significant contribution to current literature on EC, but also advances the concepts and measurement of EC, which is still somewhat unique in the context of hotel sector, especially in Malaysia. The study was undertaken to provide guidance on the inconsistent outcomes reported by prior research and an attempt to resolve the deficiencies identified in the existing research. The findings of the current study provide an in-depth understanding and guidance to policy makers and practitioners on enhancing remuneration and employee commitment. Moreover, educate the practitioners on how employees receiving adequate support from SPS and sufficient remuneration from the employer can lead to increased level of commitment and improved organizational performance.

\section{Limitations and suggestions for future research}

The current study concentrated only on large restaurant situated in Hotels of Malaysia for data collection, other sectors such as health, education, and banking sectors may also be focused on in future studies to gauge the true nature of the study's constructs. Second, survey data were collected from employees working in restaurants located in Malaysia, without considering the small-scale restaurants. Futures studies are suggested to be carried out on small scale restaurants and both the results may be compared with each other. Finally, current study considered SPS as a moderating variable, so future research may add other variables such as work environment, and managerial support as moderators or 
mediators for in-depth insights and understanding on the interaction between these variables.

\section{References}

Abeler, J., Altmann, S., Kube, S., \& Wibral, M. (2010). Gift exchange and workers' fairness concerns: when equality is unfair. Journal of the European Economic Association, 8(6), 1299-1324.

Adams, J. S., \& Jacobsen, P. R. (1964). Effects of wage inequities on work quality. The Journal of Abnormal and Social Psychology, 69(1), 19.

Ahmad, A., Abdul Majid, A. H., \& Mohd Zin, M. L. (2016). Coworker support as moderator on the relationship between HRM practices and Organizational Commitment: A proposed framework. Asian Journal of Multidisciplinary Studies, 4(4), 91-97.

Ahmad, A., Kura, K. M., Bibi, P., Khalid, N., \& rahman Jaaffar, A. (2019). Effect of Compensation, Training and Development and Manager Support on Employee Commitment: The moderating effect of Co-worker Support. Journal on Innovation and Sustainability, 10(2), 39-55.

Ahmad, A., Shah, S. M. M., Bibi, P., \& Shah, S. M. H. (2017). The Impact of Remuneration and Training and Development on Organizational Commitment. Sukkur IBA Journal of Management and Business, 4(2), 26-39.

Albrecht, S. L., \& Marty, A. (2020). Personality, self-efficacy and job resources and their associations with employee engagement, affective commitment and turnover intentions. The International Journal of Human Resource Management, 31(5), 657-681.

Ali, I., Rehman, K. U., Ali, S. I., Yousaf, J., \& Zia, M. (2010). Corporate social responsibility influences, employee commitment and organizational performance. African Journal of Business Management, 4(13), 2796-2801.

Allen, D. G., Shore, L. M., \& Griffeth, R. W. (2003). The role of perceived organizational support and supportive human resource practices in the turnover process. Journal of management, 29(1), 99118.

Aswathappa, K., \& Dash, S. (2020). International Human Resource Management: McGraw-Hill Education.

Balay, R. (2000). Organizational commitment. Ankara: Nobel Publishing.

Berberoglu, A. (2018). Impact of organizational climate on organizational commitment and perceived organizational performance: empirical evidence from public hospitals. BMC health services research, 18(1), 399.

Blau, P. M. (1964). Justice in social exchange. Sociological Inquiry, 34(2), 193-206.

Chanda, U., \& Goyal, P. (2020). A Bayesian network model on the interlinkage between Socially Responsible HRM, employee satisfaction, employee commitment and organizational performance. Journal of Management Analytics, 7(1), 105-138.

Chaudhuri, A. (2011). Sustaining cooperation in laboratory public goods experiments: a selective survey of the literature. Experimental economics, 14(1), 47-83.

Chew, J., \& Chan, C. C. (2008). Human resource practices, organizational commitment and intention to stay. International Journal of Manpower.

Chhabra, I. G., Ubeja, S., \& Sharma, S. S. (2020). EXPLORATORY RESEARCH OF FACTOR AFFECTING ORGANIZATIONAL COMMITMENT: A STUDY OF PRIVATE BANKS. Prestige International Journal of Management and Research, 11(3), 62-67.

Chiaburu, D. S., \& Harrison, D. A. (2008). Do peers make the place? Conceptual synthesis and metaanalysis of coworker effects on perceptions, attitudes, OCBs, and performance. Journal of applied psychology, 93(5), 1082.

De Rijk, A. E., Blanc, P. M. L., Schaufeli, W. B., \& De Jonge, J. (1998). Active coping and need for control as moderators of the job demand-control model: Effects on burnout. Journal of occupational and organizational psychology, 71(1), 1-18.

Ducharme, L. J., \& Martin, J. K. (2000). Unrewarding work, coworker support, and job satisfaction: A test of the buffering hypothesis. Work and occupations, 27(2), 223-243.

Ellickson, M. C., \& Logsdon, K. (2001). Determinants of job satisfaction of municipal government employees. State and Local Government Review, 33(3), 173-184. 
Hair, J. F., Anderson, R. E., Babin, B. J., \& Black, W. C. (2010). Multivariate data analysis: A global perspective (Vol. 7): Upper Saddle River, NJ: Pearson.

Ismail, A., Zainuddin, N. F. A., \& Ibrahim, Z. (2010). LINKING PARTICIPATIVE AND CONSULTATIVE LEADERSHIP STYLES TO ORGANIZATIONAL COMMITMENT AS AN ANTECEDENT OF JOB SATISFACTION. UNITAR $e$-Journal, 6(1).

Liu, C., Wang, N., \& Liang, H. (2020). Motivating information security policy compliance: The critical role of supervisor-subordinate guanxi and organizational commitment. International Journal of Information Management, 54, 102152.

McEntee, A., Roche, A. M., Kostadinov, V., Hodge, S., \& Chapman, J. (2020). Predictors of turnover intention in the non-government alcohol and other drug sector. Drugs: Education, Prevention and Policy, 1-9.

Memon, M. A., Salleh, R., Mirza, M. Z., Cheah, J.-H., Ting, H., Ahmad, M. S., \& Tariq, A. (2020). Satisfaction matters: the relationships between HRM practices, work engagement and turnover intention. International Journal of Manpower.

Mendis, M. (2017). The impact of reward system on employee turnover intention: a study on logistics industry of sri lanka. International Journal of Scientific \& Technology Research, 6(9), 67-72.

Meyer, I., \& Nujjoo, A. (2012). The relative importance of different types of rewards for employee motivation and commitment in South Africa. SA Journal of Human Resource Management, 10(2), 1-10.

Meyer, J. P., \& Allen, N. J. (1997). Commitment in the workplace: Theory, research, and application: Sage.

Milgo, A. C., Namusonge, G., Kanali, C., \& Makokha, E. N. (2014). Reward and compensation as a determinant of employee commitment: A survey of KTDA tea factories in Kenya.

Mowday, R. T., Steers, R. M., \& Porter, L. W. (1979). The measurement of organizational commitment. Journal of vocational behavior, 14(2), 224-247.

Nijhof, W. J., de Jong, M. J., \& Beukhof, G. (1998). Employee commitment in changing organizations: an exploration. Journal of European industrial training.

Porter, L. W., Steers, R. M., Mowday, R. T., \& Boulian, P. V. (1974). Organizational commitment, job satisfaction, and turnover among psychiatric technicians. Journal of applied psychology, 59(5), 603.

Saif, M. I., Malik, M. I., \& Awan, M. Z. (2011). Employee work satisfaction and work-life balance: A Pakistani perspective. Interdisciplinary journal of contemporary research in business, 3(5), 606617.

Singh, V. (2019). The Impact of Job Engagement and Organizational Commitment on Organizational Performance: Evidence from India Management Techniques for Employee Engagement in Contemporary Organizations (pp. 218-235): IGI Global.

Teclemichael Tessema, M., \& Soeters, J. L. (2006). Challenges and prospects of HRM in developing countries: testing the HRM-performance link in the Eritrean civil service. The International Journal of Human Resource Management, 17(1), 86-105.

Tran, K., Nguyen, P., Nguyen, T., \& Ton, U. (2020). The impact of organisational commitment on the relationship between motivation and turnover intention in the public sector. International Journal of Innovation, Creativity and Change, 11(12), 1-25.

Weasmer, J., \& Woods, A. M. (2002). Introduction: Teaching: An All-Terrain Career Path. The Clearing House, 75(4), 172-174. 